\title{
The relationships of concentrations of insulin, intact proinsulin and 32-33 split proinsulin with cardiovascular risk factors in Type 2 (non-insulin-dependent) diabetic subjects
}

\author{
D. K. Nagi ${ }^{1}$, T. J.Hendra ${ }^{1}$, A.J. Ryle ${ }^{2}$, T. M.Cooper ${ }^{2}$, R. C. Temple ${ }^{3}$, P.M.S. Clark ${ }^{3}$, A.E.Schneider ${ }^{3}$, \\ C.N.Hales ${ }^{3}$, and J.S. Yudkin ${ }^{1}$ \\ ${ }^{1}$ Academic Unit of Diabetes and Endocrinology, Department of Medicine and ${ }^{2}$ Department of Nutrition and Dietetics, \\ University College and Middlesex School of Medicine, Whittington Hospital, and \\ ${ }^{3}$ Department of Clinical Biochemistry, Addenbrooke's Hospital, Cambridge, UK
}

Summary. Standard radioimmunoassay for insulin may substantially overestimate levels of insulin because of cross-reaction with other insulin-like molecules. We have measured concentrations of insulin, intact proinsulin and 32-33 split proinsulin using two-site monoclonal antibody based immunoradiometric assays, and of insulin by a standard radioimmunoassay ("immunoreactive insulin") in 51 Type 2 (noninsulin-dependent) diabetic subjects in the fasting state. The relationships of these concentrations were sought with those of total cholesterol, high density lipoprotein cholesterol, low density lipoprotein cholesterol, triglyceride, plasminogen activator inhibitor, blood pressure, and indices of body fat distribution. Significant relationships were apparent between concentrations of "immunoreactive insulin" as measured by standard radioimmunoassay and triglyceride $\left(r_{\mathrm{s}}=0.42\right.$, $p<0.001)$, total cholesterol $\left(r_{\mathrm{s}}=0.25, p=0.038\right)$, high density lipoprotein cholesterol $\left(r_{\mathrm{s}}=-0.30, p=0.018\right)$ and body mass index $\left(r_{\mathrm{s}}=0.30, p=0.017\right)$, but only the relationships with triglyceride $\left(r_{\mathrm{s}}=0.36, p=0.006\right)$ and body mass index $\left(r_{\mathrm{s}}=0.26, p=0.034\right)$ remained significant when concentrations of immunoradiometrically measured insulin were employed. Concentrations of 32-33 split proinsulin, which comprises the major insulin-like molecule in these subjects, correlated positively with triglyceride $\left(r_{\mathrm{s}}=0.33, p=0.009\right)$, total cholesterol $\left(r_{\mathrm{s}}=0.23, p=0.050\right)$, and plasminogen acti- vator inhibitor $\left(r_{\mathrm{s}}=0.26, p=0.049\right)$, and negatively with high density lipoprotein cholesterol $\left(r_{\mathrm{s}}=-0.29, p=0.021\right)$. Concentrations of "immunoreactive insulin" and immunoradiometric assay insulin showed significant positive correlaion with both systolic $\left(r_{\mathrm{s}}=0.24, p=0.044\right.$ and $r_{\mathrm{s}}=0.29$, $p=0.020$ respectively), and diastolic blood pressure $\left(r_{\mathrm{s}}=0.48, p<0.001\right.$ and $r_{\mathrm{s}}=0.42, p=0.001$ respectively), while those of intact proinsulin and 32-33 split proinsulin correlated only with diastolic blood pressure $\left(r_{\mathrm{s}}=0.33\right.$, $p=0.009$ and $r_{\mathrm{s}}=0.31, p=0.014$ respectively). Using multiple regression analysis, and including age, sex, race and body mass index in the analyses, concentrations of intact proinsulin and 32-33 split proinsulin, but not immunoradiometric assay insulin, were significantly related to diastolic blood pressure. When all three molecules were incorporated into a single model, only $32-33$ split proinsulin was related to diastolic blood pressure (F-change $=6.91,[5,43$ degrees of freedom]; $p=0.012$ ). Thus, high concentrations of insulin-like molecules are associated with changes in recognised cardiovascular risk factors in patients with Type 2 (non-insulin-dependent) diabetes mellitus.

Key words: $32-33$ splet-proinsulin, Total cholesterol, high density lipoprotein cholisterol, plasminogen activator inhibitor, Blood pressure.
Patients with Type 2 (non-insulin-dependent) diabetes mellitus have a substantially increased risk of cardiovascular disease [1], the cause of which remains unexplained. Several studies, both in diabetic and non-diabetic subjects, have demonstrated a relationship between fasting hyperinsulinaemia and certain risk factors for cardiovascular disease including raised concentrations of serum triglycerides (TG) [2-4] and plasminogen activator inhibitor (PAI-1) $[5,6]$, and low concentrations of high density lipoprotein cholesterol (HDL-C). In non-diabetic subjects central obesity, a recognised risk factor for coronary artery disease and for future development of diabetes, is also associated with hyperinsulinaemia [7, 8]. Hyperinsulinaemia and insulin resistance have also been suggested as common links between glucose intolerance, obesity and hypertension [9].

Using a novel two-site monoclonal antibody-based assay, we have recently shown that a conventional radioimmunoassay of insulin substantially overestimates true insulin concentrations, and that two other insulinlike molecules, namely intact proinsulin and 32-33 split proinsulin, appear to be detected by this assay [10]. We have demonstrated that these molecules comprise the major components of the circulating insulin-like mole- 
Table 1. Clinical characteristics of Asian and Caucasian Type 2 (non-insulin-dependent) diabetic subjects

\begin{tabular}{|c|c|c|c|}
\hline & $\begin{array}{l}\text { Asian } \\
\text { subjects }\end{array}$ & $\begin{array}{l}\text { Caucasian } \\
\text { subjects }\end{array}$ & $\begin{array}{l}\text { Significance } \\
\text { of differ- } \\
\text { ence }(p)\end{array}$ \\
\hline Number & 25 & 26 & \\
\hline Age (years) & $49.8(8.9)$ & $55.4(7.5)$ & 0.02 \\
\hline $\begin{array}{l}\text { Gender } \\
\text { Male } \\
\text { Female }\end{array}$ & $\begin{array}{r}17 \\
8\end{array}$ & $\begin{array}{l}12 \\
14\end{array}$ & $>0.1$ \\
\hline $\begin{array}{l}\text { Treatment } \\
\text { Diet alone } \\
\text { Diet + Metformin } \\
\text { Diet + Sulphonylurea } \\
\text { Diet + both }\end{array}$ & $\begin{array}{r}11 \\
1 \\
10 \\
3\end{array}$ & $\begin{array}{l}9 \\
4 \\
9 \\
4\end{array}$ & $>0.5$ \\
\hline $\begin{array}{l}\text { Duration of diabetes } \\
\text { (years) }\end{array}$ & $4 \quad(0.5-16)$ & $2.7(0.75-14)$ & 0.50 \\
\hline $\begin{array}{l}\text { Fasting blood glucose } \\
(\mathrm{mmol} / \mathrm{l})\end{array}$ & $10.2(3.6)$ & $8.6 \quad(2.7)$ & 0.08 \\
\hline $\begin{array}{l}\text { Glycated haemoglobin } \\
(\%)\end{array}$ & $9.8(2.2)$ & $8.6 \quad(1.4)$ & 0.01 \\
\hline $\begin{array}{l}\text { Body mass index } \\
\left(\mathrm{kg} / \mathrm{m}^{2}\right)\end{array}$ & $24.0(18.6-40.0)$ & $27.2(21.4-38.4)$ & 0.04 \\
\hline Waist-hip-ratio & $0.92(0.06)$ & $0.88(0.07)$ & 0.08 \\
\hline $\begin{array}{l}\text { Subscapular- } \\
\text { triceps-ratio }\end{array}$ & $1.23(0.20)$ & $1.32(0.31)$ & 0.21 \\
\hline $\begin{array}{l}\text { Systolic blood } \\
\text { pressure }(\mathrm{mm} \mathrm{Hg})\end{array}$ & $120(100-160)$ & $122(91-180)$ & 0.34 \\
\hline $\begin{array}{l}\text { Diastolic blood } \\
\text { pressure (mm Hg) }\end{array}$ & $78 \quad(64-98)$ & $74(51-110)$ & 0.42 \\
\hline
\end{tabular}

$\overline{\text { Values are expressed as mean (SD) for normally distributed data or }}$ as median (range) for skewed data

cules in Type 2 diabetic subjects. We now report the results of a study applying this assay to fasting serum from 51 Type 2 diabetic outpatients participating in an investigation of ethnic differences in cardiovascular risk factors. The aims of this study were, firstly, to look at the contribution made by intact proinsulin and $32-33$ split proinsulin to the hyperinsulinaemia of Type 2 diabetes; secondly, to analyse the relationship of concentrations of insulin and its precursor molecules to those of standard cardiovascular risk factors; and thirdly, to study the contribution of insulin precursor molecules to previously reported differences in insulin levels in the two ethnic groups [11-13].

\section{Subjects, materials and methods}

The study population comprised 51 Type 2 diabetic subjects (26 Caucasian, 25 Asian) aged between 35 and 70 years. The study population represented a random sample of Type 2 diabetic subjects attending the clinic but without clinical evidence of ischaemic heart, peripheral vascular, or cerebrovascular disease, and with normal electrocardiograms. All subjects had diabetes as defined by World Health Organisation criteria [14]. All patients attended the Clinical Investigation Unit in the Department of Diabetes and Endocrinology at the Whittington Hospital, between 08.30 and 09.30 hours following a $12 \mathrm{~h}$ fast. Venous blood was taken after $15 \mathrm{~min}$ rest using a number 1 serum needle without venous stasis and with minimal trauma. Patients were weighed wearing light clothing and no shoes, and skinfold measurements were performed using Holtain calipers (Holtain Ltd., Crosswell, Crymych, Dyfed, Wales, UK), taking three measurements of subscapular and three of triceps skinfold thickness.
Waist and hip girth measurements were taken using a steel tape. Waist-to-hip (WHR) and subscapular-to-triceps (STR) skinfold ratios were estimated, and body mass index (BMI) was calculated (weight in $\mathrm{kg} /$ height in meters ${ }^{2}$ ). Blood pressure was measured in the sitting position with a mercury sphygmomanometer.

Blood glucose was analysed using a glucose oxidase method (Beckman Analyser, Beckman Instruments, Brea, Calif., USA) and glycated haemoglobin by electroendosmosis (Corning Ltd, Halstead, Essex, UK). Immunoreactive insulin was measured using a standard kit based on a polyclonal antibody $\left({ }^{125}\right.$ I-Tyr A19 human insulin RIA kit, Novo Pharmaceuticals, Basingstoke, Hants, UK). Because of our findings that this assay appears to cross-react stoichiometrically with intact and 32-33 split proinsulin [10], we refer to these results as "immunoreactive insulin" ("IRI"). Insulin, intact proinsulin and 32-33 split proinsulin were measured using highly specific two-site monoclonal antibody based immunoradiometric assays (IRMA) [15]. PAI-1 was measured using a spectrophotometric method [16]. The results of PAI-activity were expressed as arbitrary units-ml, one arbitrary unit of inhibitor being defined as the amount which inhibits one international unit of tissue plasminogen activator. Total cholesterol (Chol) and triglyceride (TG) were measured by enzymatic methods $[17,18]$ using an Encore analyser (Baker Instruments Ltd., Windsor, Berkshire, UK). HDL-C was measured using the same method after precipitation of VLDL and LDL using a magnesium chloride/phosphotungstate reagent. Low density lipoprotein cholesterol (LDL-C) was calculated using the Friedewald equation [19].

The study was approved by the Ethical Committee of Islington Health Authority.

\section{Statistical analysis}

Group differences were analysed using Student's $t$-test for normally distributed data and Mann-Whitney U-test for skewed data (body mass index, systolic and diastolic blood pressure, and concentrations of "IRI", IRMA insulin, intact proinsulin, 32-33 split proinsulin,

Table 2. Correlation coefficients of insulin and insulin-like molecules with clinical and biochemical variables in all subjects

\begin{tabular}{lcccc}
\hline & $\begin{array}{l}\text { "Immuno- IRMA } \\
\text { reactive } \\
\text { insulin" }\end{array}$ & $\begin{array}{l}32-33 \text { split } \\
\text { insulin }\end{array}$ & $\begin{array}{l}\text { Intact } \\
\text { proinsulin }\end{array}$ & proinsulin \\
\hline Age & -0.22 & -0.06 & $-0.42^{\mathrm{b}}$ & $-0.32^{\mathrm{b}}$ \\
$\begin{array}{l}\text { Body mass } \\
\text { index }\end{array}$ & $0.30^{\mathrm{a}}$ & $0.26^{\mathrm{a}}$ & 0.22 & 0.14 \\
Waist-hip-ratio & 0.16 & -0.03 & 0.19 & 0.18 \\
$\begin{array}{l}\text { Subscapular- } \\
\text { triceps-ratio }\end{array}$ & 0.08 & -0.02 & -0.03 & 0.05 \\
Fasting glucose & 0.09 & 0.03 & 0.17 & $0.26^{\mathrm{a}}$ \\
Total Cholesterol & $0.25^{\mathrm{a}}$ & 0.17 & $0.23^{\mathrm{a}}$ & 0.21 \\
Triglyceride & $0.42^{\mathrm{c}}$ & $0.36^{\mathrm{b}}$ & $0.33^{\mathrm{b}}$ & $0.29^{\mathrm{a}}$ \\
HDL-Cholesterol & $-0.30^{\mathrm{a}}$ & -0.06 & $-0.29^{\mathrm{a}}$ & $-0.29^{\mathrm{a}}$ \\
$\begin{array}{l}\text { LDL-Cholesterol } \\
\text { PAI-1 }\end{array}$ & 0.11 & 0.01 & 0.09 & 0.11 \\
$\begin{array}{l}\text { Systolic blood } \\
\text { pressure }\end{array}$ & 0.14 & 0.08 & $0.26^{\mathrm{a}}$ & 0.13 \\
$\begin{array}{l}\text { Diastolic blood } \\
\text { pressure }\end{array}$ & $0.24^{\mathrm{a}}$ & $0.29^{\mathrm{a}}$ & 0.14 & 0.17 \\
\hline & $0.48^{\mathrm{c}}$ & $0.42^{\mathrm{c}}$ & $0.31^{\mathrm{a}}$ & $0.33^{\mathrm{b}}$ \\
\hline
\end{tabular}

${ }^{\mathrm{a}} p<0.05 ;{ }^{\mathrm{b}} p<0.01 ;{ }^{\mathrm{c}} p<0.001$

All analyses were performed using Spearman rank correlation. IRMA - immunoradiometric assay; PAI-1 - plasminogen activator inhibitor 
Table 3. Multiple regression analysis for determinants of diastolic blood pressure in 51 Type 2 (non-insulin-dependent) diabetic subjects

\begin{tabular}{lllll}
\hline Variable in model & Variable added & F Change (d.f.) & Multiple $r^{2}$ & Significance \\
\hline & Sex & $0.01(1,47)$ & 0.0002 & 0.918 \\
Sex & Race & $1.33(2,46)$ & 0.028 & 0.254 \\
Sex, race & Age & $2.36(3,45)$ & 0.077 & 0.132 \\
Sex, race, age & BMI & $4.71(4,44)$ & 0.166 & 0.036 \\
Sex, race, age, BMI & $32-33$ split proinsulin & $6.91(5,43)$ & 0.277 & 0.012 \\
Sex, race, age, BMI, 32-33 split proinsulin & IRMA insulin & $0.56(6,42)$ & 0.287 & 0.457 \\
Sex, race, age, BMI, 32-33 split proinsulin, IRMA insulin & Intact proinsulin & $0.31(7,41)$ & 0.296 \\
\hline
\end{tabular}

IRMA - immunoradiometric assay

Table 4. Values of insulin, insulin-like molecules, lipids and plasminogen activator inhibitor in Asian and Caucasian Type 2 (non-insulin-dependent) diabetic subjects

\begin{tabular}{lccc}
\hline & Asians & Caucasians & Significance of difference \\
\hline Number & 25 & 26 & 0.18 \\
IRMA insulin (pmol/l) & $45.5(10-116)$ & $34.0(14-78)$ & 0.07 \\
Intact proinsulin (pmol/l) & $23.0(2.4-52)$ & $13.4(1.6-46)$ & 0.01 \\
32-33 split proinsulin (pmol/l) & $66.0(15-237)$ & $37.5(11-167)$ & 0.04 \\
Sum of IRMA insulin, intact proinsulin & & & \\
and 32-33 split proinsulin (pmol/l) & $130.0(44-372)$ & $91.0(33.2-285)$ & 0.12 \\
Immunoreactive insulin (pmol/l) & $111.9(34.2-371.8)$ & $92.8(56.9-260.6)$ & 0.36 \\
Total Cholesterol (mmol/l) & $5.67(1.12)$ & $5.96(1.13)$ & 0.57 \\
Triglyceride (mmol/l) & $2.0(0.5-22.4)$ & $1.6(0.5-10.0)$ & 0.82 \\
HDL-Cholesterol (mmol/l) & $0.97(0.17)$ & $0.98(0.20)$ & 0.13 \\
LDL-Cholesterol (mmol/l) & $3.71(0.90)$ & $4.17(1.15)$ & 0.34 \\
PAI-1 (AU/ml) & $10.2(5-51)$ & $9.2(4-42)$ & \\
\hline
\end{tabular}

Values are expressed as mean (SD) for normally distributed data or as median (range) for skewed data. IRMA - immunoradiometric assay; PAI-1 - Plasminogen activator inhibitor

triglyceride and PAI-1). Correlations were sought using linear regression analysis for normally distributed data and Spearman-rank correlation for skewed data. Analysis of variance was used in order to study the independent relationship between two variables while allowing for confounding variables. Multiple regression analyses were performed with logarithmic transformation of the skewed data. Values are expressed as mean (SD) for normally distributed data and median (range) for skewed data.

\section{Results}

The patients' characteristics are shown in Table 1. Asian and Caucasian patients were similar in terms of treatment and gender; however, the Asian patients were younger and thinner, had longer duration of diabetes and worse glycaemic control than their Caucasian counterparts.

The major insulin-like molecule was 32-33 split proinsulin which comprised a mean of $47.8 \%$ (SD $12.4 \%$ ) of the sum of three molecules, while IRMA insulin represented $37.7 \%$ (SD $15.0 \%$ ) of the sum of the molecules. In these subjects, the concentrations of "immunoreactive insulin" ("IRI") using the standard radioimmunoassay, were $99.1 \%$ (SD 25.9) of the sum of the concentrations of all three insulin-like molecules as measured by IRMA. We have published elsewhere our findings on the cross-reactivity of the "IRI" assay with intact and 32-33 split proinsulin, on the specificity of the IRMA assays for these in- sulin-like molecules, and on the relationship between these assays [10].

There were significant positive relationships between concentrations of "IRI" and those of Chol and TG, and a negative correlation with HDL-C (Table 2). The relationships with LDL-C and PAI-1 were not significant. When the relationships of concentrations of lipids and PAI-1 were sought with concentrations of insulin measured by the two site monoclonal antibody, only that with TG was significant. Concentrations of 32-33 split proinsulin correlated positively with those of Chol, TG, and PAI-1 and negatively with that of HDL-C. The relationship between concentrations of these molecules and those of cholester$\mathrm{ol}$, TG and PAI- 1 were little affected by including sex, age, race and body mass index in a multiple regression analyses, although those with HDL-C were weakened in such an analysis.

Concentrations of "IRI" and IRMA insulin showed significant positive correlations with both systolic and diastolic blood pressure while 32-33 split proinsulin and intact proinsulin correlated with diastolic blood pressure only. Multiple regression analysis was used to study the independent relationships of the insulin-like molecules with diastolic blood pressure. When concentrations of IRMA insulin were entered into the model after age, sex, race and body mass index, the relationship with diastolic blood pressure was not significant $(\mathrm{F}$ change $=2.51[3,45 \mathrm{df}]$; $p=0.12$ ), but both 32-33 split proinsulin and intact proin- 
sulin remained as significant additional determinants in separate models $(\mathrm{F}=4.67[4,44 \mathrm{df}] ; p=0.036$ and $\mathrm{F}=4.40$ $[4,44 \mathrm{df}] ; p=0.042$ respectively). When all three insulinlike molecules were entered into the model, the significance of F-change for 32-33 split proinsulin was the largest, and neither of the other molecules significantly improved the model (Table 3). In similar analyses with systolic blood pressure as the dependent variable, none of the insulin-like molecules made a significant contribution to the model when entered after age, sex, race and body mass index.

Concentrations of 32-33 split proinsulin were higher in the Asian than Caucasian subjects (Table 4), but when compared using analysis of variance to include treatment, gender and age in the analysis, these differences were no longer significant. There was no significant effect of treatment categories or gender on concentrations of any of the insulin-like molecules.

\section{Discussion}

Hyperinsulinaemia, and insulin resistance, are associated with elevated concentrations of TG and low concentrations of HDL-C in both non-diabetic and Type 2 diabetic subjects [4]. More recently hyperinsulinaemia has been shown to be associated with increased concentrations of PAI-1 in obese non-diabetic subjects $[5,6]$ and also in subjects with ischaemic heart disease $[20,21]$. The mechanism by which these metabolic changes occur are incompletely understood, but may involve an effect of peripheral insulin resistance in conjunction with a hepatic effect mediated by high portal insulin concentrations. Elevated levels of insulin have also been demonstrated in subjects with essential hypertension $[22,23]$.

Insulin is produced in the pancreatic Beta cell from its precursor molecule proinsulin. During the process of insulin secretion in normal subjects small amounts of proinsulin are also released into the circulation. Several studies have shown a disproportionate elevation in circulating proinsulin concentrations in various disease states including Type 2 diabetes [24, 25], where these high concentrations are thought to result from the secretion from the pancreas of the contents of immature granules which contain a higher ratio of proinsulin to insulin.

Recently the use of highly specific 2-site assays has permitted the measurement of split forms of proinsulin in the circulation $[10,15]$, and elevated concentrations of 32-33 split proinsulin have been reported both in nonobese and obese subjects with Type 2 diabetes [10, 26]. The observation that both split and intact proinsulin seem to be measured by a standard insulin radioimmunoassay suggest that hyperinsulinaemia demonstrated in some of the studies of subjects with Type 2 diabetes $[4,27,28]$ may have resulted from overestimation of concentrations of insulin by cross-reactivity with other insulin-like molecules, in particular 32-33 split proinsulin.

In this study, we have confirmed our previous observation that the insulin concentrations of Type 2 diabetic subjects are exaggerated by the use of conventional radioimmunoassays, with two thirds of the concentrations of "IRI" comprising intact and 32-33 split proinsulin. We have also shown that the relationships between concentrations of "IRI" and of total and HDL-cholesterol in this study population were no longer significant when concentrations of IRMA insulin were used in the analyses, suggesting that the relationships with "IRI" are a reflection of the correlations found between these concentrations and those of intact and split proinsulin which were cross-reacting in this standard radioimmunoassay. We have been unable to demonstrate any relationships of "IRI" or IRMA insulin with PAI-1, while 32-33 split proinsulin did show a significant relationship with PAI-1. Moreover, while levels of all the insulin-like molecules related to diastolic blood pressure, that of 32-33 split proinsulin appeared to be the most important in multiple regression analyses. Previous findings have suggested that hyperinsulinaemia may correlate with both systolic and diastolic blood pressure [22,29-31], but we found no independent association with systolic blood pressure in this population. It should be noted, however, that there was a low prevalence of hypertension in this population and thus the range of blood pressure readings was narrow.

Even though intact proinsulin and 32-33 split proinsulin are the major circulating insulin-like molecules in the Type 2 diabetic subjects studied here, the relationships we have found do not necessarily signify a cause and effect relationship with cardiovascular risk factors. We would, however, like to speculate on a possible underlying metabolic basis for these relationships. Intact proinsulin in rat lymphocyte, adipocyte and hepatocyte systems shows receptor binding which is of the order of $0.5-2.0 \%$ of that of insulin [32]. However, metabolic studies in human subjects have demonstrated that intact proinsulin appears to exert a more profound metabolic effect than the in-vitro studies would suggest, with around $12 \%$ of the biological activity of insulin on suppression of hepatic glucose output [33] and $20 \%$ of the action of insulin in stimulating PAI-1 synthesis in isolated liver tumour cells [34]. Receptor binding studies suggest that 32-33 split proinsulin has five-fold greater affinity than intact proinsulin in isolated rat cell models [32]. Thus, if the molar ratio of 32-33 split proinsulin to insulin in Type 2 diabetes is $2: 1$, split proinsulin might in theory have approximately equal, or even greater, metabolic influence compared with insulin in such patients, particularly on hepatic metabolism.

Recently, hyperinsulinaemia has been implicated in the cation transport abnormalities that characterise hypertension, obesity and glucose intolerance [35], perhaps through its action on the $\mathrm{Na}^{+} / \mathrm{H}^{+}$exchange [36]. Insulin leads to renal sodium retention [37] and may also have a stimulating effect on the sympathetic nervous system [38]. Our findings, that 32-33 split proinsulin correlates with levels of diastolic blood-pressure in these Type 2 diabetic subjects, suggest that this molecule may have similar actions to insulin on the renal tubule or the sympathetic nervous system, but such speculation would require experimental confirmation. 
In conclusion, the elevated concentrations of intact proinsulin and 32-33 split proinsulin in subjects with Type 2 diabetes [26] are associated with deleterious changes in levels of recognised cardiovascular risk factors. It is suggested that previously described associations between hyperinsulinaemia and elevated levels of cardiovascular risk factors in Type 2 diabetes may be a consequence of elevated concentrations of these insulin-like molecules. Hyperinsulinaemia has also been linked to an increased incidence or prevalence of cardiovascular disease, both in population studies and in groups of non-diabetic subjects at high risk of cardiovascular disease [13, 39-41]. Reaven has introduced the concept of Syndrome $X$, a combination of glucose intolerance, hyperinsulinaemia, increased VLDL-TG, decreased HDL-C and hypertension, with insulin resistance proposed as the common factor for these related variables [42]. It remains to be seen whether elevated concentrations of proinsulin-like molecules are also relevant to determining the concentrations of these variables in nondiabetic subjects.

Acknowledgements. We are grateful to Dr. J.Bell, Department of Biochemistry, Royal Free Hospital, London, for performing the lipid estimations, to Mr. R. Hughe, University Department of Medicine, Leeds Infirmary, for PAI-1 assays, Mr. M.Brown and Mr. J. Wager for technical assistance. This work was supported by the British Diabetic Association, Eli Lilly, Novo Industri A/S, Copenhagen and the East Anglian Regional Health Authority for locally organised research. DKN is supported by Lipha Pharmaceuticals Ltd.

\section{References}

1. Garcia MJ, McNamara PM, Gordon T, Kannel WB (1974) Morbidity and mortality in diabetics in the Framingham population. Sixteen year follow-up study. Diabetes 23: 105-111

2. Orchard TJ, Becker DJ, Bates M, Kuller LH, Drash AL (1983) Plasma insulin and lipoprotein concentrations: an atherogenic association? Am J Epidemiol 118: 326-337

3. Olefsky JM, Farquhar JW, Reaven GM (1974) Reappraisal of the role of insulin in hypertriglyceridemia. Am J Med 57: 551-559

4. Laasko M, Pyörälä K, Voutilainen E, Marniemi J (1987) Plasma insulin and serum lipids and lipoprotein in middle aged non-insulin-dependent diabetic and non-diabetic subjects. Am J Epidemiol 125: 611-621

5. Juhan-Vague I, Vague Ph, Alessi MC, Badier C, Valadier J, Aillaud MF, Atlan C (1987) Relationship between plasma insulin, triglyceride, body mass index, and plasminogen activator inhibitor-1. Diab Metab 13: 331-336

6. Vague Ph, Juhan-Vague I, Aillaud MF, Badier C, Viard R, Alessi MC, Collen D (1986) Correlation between blood fibrinolytic activity, plasminogen activator inhibitor levels, plasma insulin and relative body weight in normal and obese subjects. Metabolism 35: 250-253

7. Kissebah AH, Vydelingum N, Murray R, Evans DJ, Hartz AJ, Kalkhoff RK, Adams PW (1982) Relation of body fat distribution to metabolic complications of obesity. J Clin Endocrinol Metab 54: 254-260

8. Stern M, Haffner SM (1986) Body fat distribution and hyperinsulinemia as risk factors for diabetes and cardiovascular disease. Arteriosclerosis 6: 123-130

9. Modan M, Halkin H, Almog S, Lusky A, Eshkol A, Shefi M, Shitrit A, Fuchs Z (1985) Hyperinsulinemia. A link between hyper- tension, obesity and glucose intolerance. J Clin Invest 75: 809817

10. Temple RC, Clark P, Schneider A, Nagi DK, Hendra TJ, Yudkin JS, Hales CN (1990) Radioimmunoassay may overestimate insulin in non-insulin-dependent diabetics. Clin Endocrinol 32: 689-693

11. Mohan V, Sharp PS, Cloke HR, Burrin JM, Schumer B, Kohner EM (1986) Serum immunoreactive insulin responses to a glucose load in Asian Indian and European Type 2 (non-insulin-dependent) diabetic patients and control subjects. Diabetologia 29: 235-237

12. Sharp PS, Mohan V, Levy JC, Mather HM, Kohner EM (1987) Insulin resistance in patients of Asian Indian and European origin with non-insulin-dependent diabetes. Horm Metab Res 19: 84-85

13. McKeigue PM, Marmot MG, Syndercombe Court YD, Cottier DE, Rahman S, Riemersma RA (1988) Diabetes, hyperinsulinaemia, and coronary risk factors in Bangledeshis in East London. Br Heart J 60: 390-396

14. World Health Organisation (1985) Diabetes mellitus: Report of a WHO Study Group. Technical Report Series No 727. WHO, Geneva

15. Sobey WJ, Beer SF, Carrington CA, Clark PMS, Frank BH, Gray P, Luzio S, Owens DR, Schneider AE, Siddle K, Temple RC, Hales CN (1989) Sensitive and specific two-site immunoradiometric assays to human insulin, proinsulin, 65-66 split and 32-33 split proinsulin. Biochem J 260: 535-541

16. Verheijen JH, Chang GT, Kluft C (1984) Evidence for the occurence of a fast acting inhibitor of tissue-type plasminogen activator in human plasma. Thromb Haemostas 51:392-395

17. Roeschlau P, Bernt E, Gruber W (1974) Enzymatic determination of total cholesterol in serum. Z Klin Chem Klin Biochem 12 226

18. Bucolo G, David H (1973) Quantitative determination of serum triglyceride by the use of enzymes. Clin Chem 19: 476-482

19. Friedewald WT, Levy RI, Fredrickson DS (1972) Estimation of the concentration of low-density lipoprotein-cholesterol in plasma, without use of the preparative ultracentifruge. Clin Chem 18: 499-502

20. Hamstèn A, Wiman D, de-Faire U, Blomback M (1985) Increased plasma levels of a rapid inhibitor of tissue plasminogen activator in young survivors of myocardial infarction. $\mathbf{N}$ Engl $\mathbf{J}$ Med 313: 1557-1563

21. Hamstèn A, Walladius G, Szamosi A, de-Faire U, Dahlen G, Landou C, Wiman B, Blomback M (1987) Plasminogen activator inhibitor in plasma: risk factors for recurrent myocardial infarction. Lancet II: 3-8

22. Bonora E, Zavaroni I, Alpi O, Pezzarossa A, Bruschi F, Dall'Aglio E, Guerra L, Coscelli C, Butturini U (1987) Relationship between blood pressure and plasma insulin in non-obese and obese non-diabetic subjects. Diabetologia 30 : 719-723

23. Ferrannini E, Buzzigoli G, Bonadonna R, Giorico MA, Oleggini M, Graziadei L, Pedrinelli R, Brandi L, Bevilacqua S (1987) Insulin resistance in essential hypertension. N Engl J Med 317: 350-357

24. Ward WK, Lacava EC, Paquette TL, Beard JC, Wallum BJ, Porte Jr D (1987) Disproportionate elevation of immunoreactive proinsulin in type-2 (NIDDM) diabetes mellitus and in experimental insulin resistance. Diabetologia 30:698-702

25. Yoshioka N, Kuzuya T, Matsuda A, Taniguchi M, Iwamoto $Y$ (1988) Serum proinsulin levels at fasting and after oral glucose load in patients with Type 2 (non-insulin-dependent) diabetes mellitus. Diabetologia 30: 355-360

26. Temple RC, Carrington CA, Luzio SD, Owens DR, Schneider AE, Sobey WJ, Hales CN (1989) Highly specific insulin assay reveals uniform insulin deficiency in non-insulin-dependent diabetics. Lancet I: 293-295

27. Gerich JE (1988) Role of insulin resistance in the pathogenesis of type 2 (non-insulin-dependent) diabetes mellitus. Clin Endocrinol Metab 2: 307-326 
28. Turner RC, Holman RR, Matthews DR, Peto J (1982) Relative contributions of insulin deficiency and insulin resistance in maturity-onset diabetes. Lancet I: 596-598

29. Haffner SM, Fong D, Hazuda HP, Pugh JA, Patterson JK (1988) Hyperinsulinemia, upper body obesity, and cardiovascular risk factors in non-diabetics. Metabolism 37:338-345

30. Christleib AR, Krolewski AS, Warram JH, Soeldner JS (1985) Is insulin the link between hypertension and obesity? Hypertension 7 [Supp1 2]: II54-II57

31. Fournier AM, Gadia MT, Kubrusly DB, Skyler JS, Sosenko JM (1986) Blood pressure, insulin and glycemia in non-diabetic subjects. Am J Med 80: 861-864

32. Peevy DE, Brunner MR, Duckworth WC, Hooker CS, Frank BH (1985) Receptor binding and biological potency of several split forms (conversion intermediates) of human proinsulin. J Biol Chem 260: 13989-13994

33. Revers RR, Henry R, Schmeiser L, Kolterman O, Cohen R, Bergenstal R, Polonsky K, Jaspan J, Rubenstein A, Frank B, Galloway J, Olefsky JM (1984) The effects of biosynthetic human proinsulin on carbohydrate metabolism. Diabetes 33: 762-770

34. Alessi MC, Juhan-Vague I, Kooistra T, Declerck PJ, Collen D (1988) Insulin stimulates the synthesis of plasminogen activator inhibitor- 1 by human hepatocellular cell lines Hep $\mathrm{G}_{2}$. Thromb Haemostas 60: 491-494

35. Halkin H, Modan M, Shefi M, Almog S (1988) Altered erythrocyte and plasma sodium and potassium in hypertension, a facet of hyperinsulinemia. Hypertension 11: 71-77

36. Rosic NK, Standaert ML, Pollet RJ (1985) The mechanism of insulin stimulation of $\left(\mathrm{Na}^{+}, \mathrm{K}^{+}\right)$-ATPase transport activity in muscle. J Biol Chem 260: 6206-6212
37. De Fronzo RA (1981) The effect of insulin on renal sodium metabolism: a review with clinical implications. Diabetologia 21: $165-171$

38. Landsberg L (1986) Diet, obesity and hypertension: an hypothesis involving insulin, the sympathetic nervous system, and adaptive thermogenesis. Quart J Med 236: 1081-1090

39. Pyörälä K (1979) Relationship of glucose tolerance and plasma insulin to the incidence of coronary heart disease: results from two population studies in Finland. Diab Care 2: 131-141

40. Welborn TA, Wearne K (1979) Coronary heart disease incidence and cardiovascular mortality in Busselton with reference to glucose and insulin concentrations. Diab Care 2: 154-160

41. Ducimetiere P, Eschwege E, Papoz L, Richard JL, Claude JR, Rosselin G (1980) Relationship of plasma insulin levels to the incidence of myocardial infarction and coronary heart disease mortality in a middle-aged population. Diabetologia 19:205-210

42. Reaven GM (1988) Role of insulin resistance in human disease. Diabetes 37: 1595-1607

Received: 2 October 1989

and in revised form: 14 March 1990

Dr. J.S. Yudkin

Academic Unit of Diabetes and Endocrinology

Whittington Hospital

Archway Road

London N195NF

UK 